\title{
Indolylimidazoles: Synthetic approaches and biological activities
}

\author{
Narendra Nirwan ${ }^{\mathrm{a}}$, Chandresh Pareek $^{\mathrm{a}}$ and V. K. Swami ${ }^{\mathrm{b}}$ \\ ${ }^{a}$ Heterocyclic research Lab. Department of Chemistry, S. D. Govt. College, Beawar, India \\ ${ }^{b}$ Department of Chemistry, Govt. Lohia PG College, Churu, India \\ C H R O N I C L E \\ Article history: \\ Received June 12, 2019 \\ Received in revised form \\ June 30, 2019 \\ Accepted July 7, 2019 \\ Available online \\ July 7, 2019 \\ Keywords: \\ Imidazole \\ Pharmacological activities \\ Anticancer \\ Amberlyst A-15 \\ Microwave irradiation
}

\section{Introduction}

Indolylimidazole and its derivatives are an important class of heterocycles. From the literature survey, it followed that the presence of imidazole ring in natural and synthesized compounds have shown significant biological activities. It has also appeared that indole ring-containing natural and synthesized compounds have also shown vast biological activities.

Indolylimidazole compounds that contain both indole and imidazole rings have showed various biological and pharmacological activities such as protein kinase $\mathrm{C}$ inhibitor, interleukin- 6 production inhibitor, MRSA PK inhibitor, Fms-like tyrosine kinase-1 (Flt-1) and topoisomerase inhibitor, antiplasmodial, anti-depressants, antimicrobial, antifungal, antibacterial, anti-urease, antioxidant and radio-sensitizing activities. These compounds also showed anticancer, cytotoxicity against murine tumour cells and P388 cells.

\subsection{Natural Bioactive Indolylimidazoles}

Indolylimidazole structure resembling compounds such as Topsentin was first reported in 1987 and isolated from marine sponges. ${ }^{1-4}$ These Topsentin (Fig. 1) and its derivatives (Fig. 2 to Fig. 5) showed different types of biological activities such as antifungal, ${ }^{5}$ antibacterial, ${ }^{6}$ antiviral, ${ }^{6}$ antitumor ${ }^{7-9}$ and anti-inflammatory ${ }^{10,11}$.

* Corresponding author.

E-mail address: drnirwann@gmail.com (N. Nirwan)

(C) 2020 by the authors; licensee Growing Science, Canada

doi: $10.5267 /$ j.ccl.2019.007.001 
<smiles>O=C(c1ncc(-c2c[nH]c3ccccc23)[nH]1)c1c[nH]c2cc(O)ccc12</smiles>

Fig. 1. Structure of Topsentin<smiles>O=C(c1ncc(-c2c[nH]c3cc(Br)ccc23)[nH]1)c1c[nH]c2cc(O)ccc12</smiles>

Fig. 2. Structure of Bromotopsentin<smiles>O=C(c1ncc(-c2c[nH]c3ccccc23)[nH]1)c1c[nH]c2ccccc12</smiles>

Fig. 3. Structure of Deoxytopsentin<smiles>O=C(c1ncc(-c2c[nH]c3cc(Br)ccc23)[nH]1)c1c[nH]c2cc(Br)ccc12</smiles>

Fig. 4. Structure of Dibromodeoxytopsentin<smiles>O=C(c1ncc(-c2c[nH]c3cc(O)ccc23)[nH]1)c1c[nH]c2cc(O)ccc12</smiles>

Fig. 5. Structure of Hydroxytopsentin

Indolylimidazole skeleton containing Nortopsentins A-C (Fig. 6 to Fig. 8) isolated from the deep sea sponge spongosoritesruetzler and showed in vitro cytotoxicity against P388 cells (IC50 4.0-18.3 $\mu \mathrm{M})^{12}$ and antifungal properties. Nortopsentin-A exhibited antiplasmodial activity and inhibited parasite growth at the trophozoite stage at submicromolar 50\% inhibitory concentrations (IC50). ${ }^{13}$ Nortopsentins-D (Fig. 9) and $\mathrm{N}$-methyl substituted derivatives of Nortopsentin also showed cytotoxicity against P388 cells (IC50 0.6-1.6 $\mu \mathrm{M}){ }^{5}$<smiles>Brc1ccc2c(c1)NCC2c1c[nH]c(C2CNc3cc(Br)ccc32)n1</smiles>

Fig. 6. Structure of Nortopsentin-A<smiles>Brc1ccc2c(c1)NCC2c1c[nH]c(C2CNc3ccccc32)n1</smiles>

Fig. 8. Structure of Nortopsentin-C

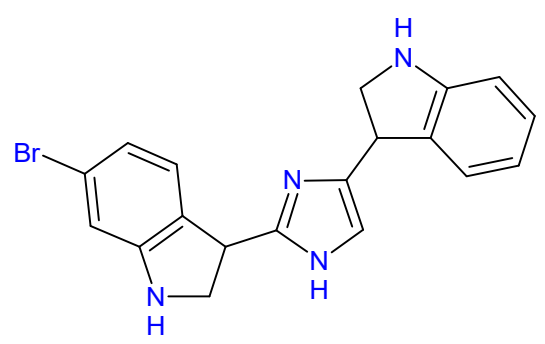

Fig. 7. Structure of Nortopsentin-B<smiles>c1ccc2c(c1)NCC2c1c[nH]c(C2CNc3ccccc32)n1</smiles>

Fig. 9. Structure of Nortopsentin D

Discodermindole (Fig. 10) has been isolated and exhibited cytotoxicity against murine tumor cells. ${ }^{14}$ 2-(Dimethylamino)-5-(1H-indol-3-yl)-4H-imidazol-4-one (Fig. 11) has isolated from the tunicate Dendrodoa grossularia and it showed cytotoxicity against murine tumor cells. ${ }^{15}$ 
<smiles>NC1=NC(c2c(Br)[nH]c3ccc(Br)cc23)CN1</smiles>

Fig. 10. Structure of Discodermindole<smiles>CNC1=NC(=O)C(c2c[nH]c3ccccc23)=N1</smiles>

Fig. 11. Structure of 2-(Dimethylamino)-5-(1H-indol-3-yl)-4H-imidazol-4-one

Trachycladindole A-G compounds are the product of southern Australian marine sponge Trachycladuslae vispirulifer. The Trachycladindole (Fig. 12) displayed promising selective cytotoxicity against a panel of human cancer cell lines. ${ }^{16}$<smiles>CN1C(=[NH2+])N(C)C(c2c(C(=O)[O-])[nH]c3ccc(Br)cc23)C1O</smiles>

Fig. 12. Structure of Trachycladindole<smiles>CN1c2ccc(F)cc2CC1C1=NCCN1</smiles>

Fig. 13. Structure of 2-(4,5-Dihydro- $1 H$-imidazol-2-yl)-5-fluoro-1-methyl-2,3-dihydro- $1 H$-indole

2-(4,5-Dihydro-1 $H$-imidazol-2-yl)-5-fluoro-1-methyl-2,3-dihydro- $1 H$-indole (Fig. 13) has shown anti-depressant activities. ${ }^{17}$ 5-(1H-indol-3-yl)-1-(1-methyl- $1 H$-indol-3-yl)-1,3-dihydro- $2 H$-imidazol2-one (Fig. 14) has been reported as a protein kinase $\mathrm{C}$ inhibitor. ${ }^{18,19}$ 
<smiles>Cn1cc(-n2c(-c3c[nH]c4ccccc34)c[nH]c2=O)c2ccccc21</smiles>

Fig. 14. Structure of 5-(1H-indol-3-yl)-1-(1-methyl-1H-indol-3-yl)-1,3-dihydro-2H-imidazol-2-one

3-\{2-(4-Methylphenyl)-5-[4-(trifluoromethyl)-phenyl]-1H-imidazol-4-yl $\}-1 H$-indole (Fig. 15) has been reported as interleukin 6-production inhibitor. ${ }^{20} 3$-(1-Alkyl-1H-imidazol-4-yl)-1H-indole (Fig. 16) and 3-(1-alkoxyalkyl-1H-imidazol-4-yl)-1H-indole derivatives (Fig. 17) have been reported as Flt-1 and topoisomerase inhibitor. ${ }^{21}$<smiles>Cc1ccc(-c2nc(-c3c[nH]c4ccccc34)c(-c3ccc(C(F)(F)F)cc3)[nH]2)cc1</smiles>

Fig. 15. Structure of 3-\{2-(4-Methylphenyl)-5-[4-(trifluoromethyl)-phenyl]-1H-imidazol-4-yl $\}-1 H$-indole<smiles>[R]n1cnc(-c2c[nH]c3ccccc23)c1</smiles>

$$
\mathrm{R}=\mathrm{Alkyl}
$$

Fig. 16. Structure of 3-(1-Alkyl- $1 H$-imidazol-4-yl)- $1 H$-indole<smiles>[R]On1cnc(-c2c[nH]c3ccccc23)c1</smiles>

$$
\mathrm{R}=\text { Alkyl }
$$

Fig. 17. Structure of 3-(1-alkoxyalkyl-1H-imidazol-4-yl)- $1 H$-indole 
Rhopaladins A-D (Fig. 18) compounds have been isolated from Okinawan tunicate Rhopalaea sp. in 1998. These compounds reported as an antibacterial agent against Sarcinalutea, Corynebacterium xerosis and showed inhibiting activity against cyclin-dependent kinase-4 and cerb $\beta-2$ kinase. ${ }^{22}$

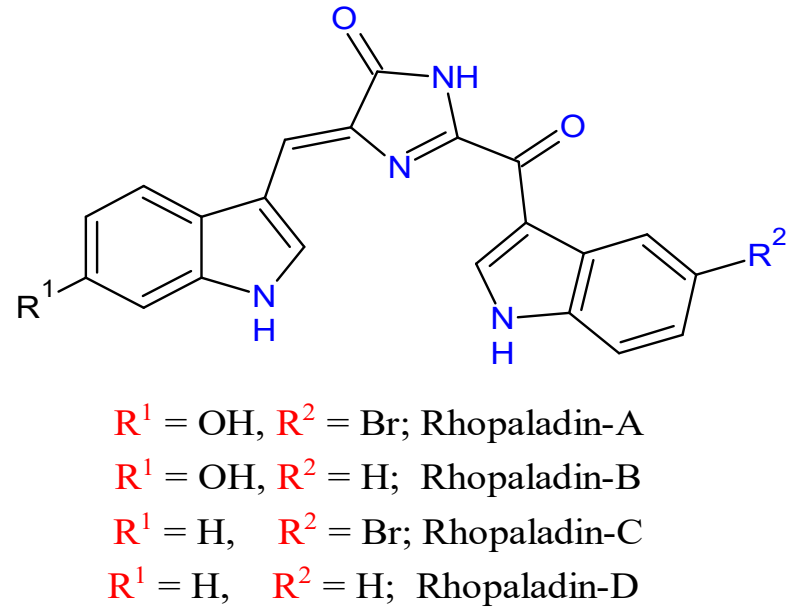

Fig. 18. Structure of Rhopaladins A-D

5-(benzyloxy)-3-[1-(1,2,3,4-tetrahydronaphthalen-1-yl)-1 $H$-imidazol-5-yl]-1H-pyrrolo[2,3c]pyridine (Fig. 19) acted as antibiotic and antitumor agent. ${ }^{23}$

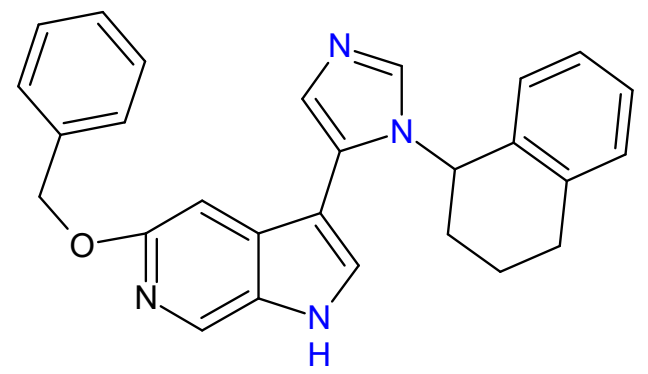

Fig. 19. Structure of indolylimidazole derivative

\subsection{Synthesized Bioactive Indolylimidazoles}

(5Z)-5-[(1-Benzyl-1H-indol-3-yl)-methylidene]-imidazolidine-2,4-dione (Fig. 20) has been synthesized and reported as radio-sensitizer against HT-29 cell line. (5Z)-5-[(1-(4-substitutedbenzyl)$1 H$-indol-3-yl)-methylidene]-imidazolidine-2,4-dione (Fig. 21) derivative also exhibited strong radio-sensitizing activities. ${ }^{24}$<smiles>O=C1NC(=O)/C(=C/c2cn(Cc3ccccc3)c3ccccc23)N1</smiles>

Fig. 20. Structure of (5Z)-5-[(1-Benzyl-1H-indol-3-yl)-methylidene]-imidazolidine-2,4-dione 


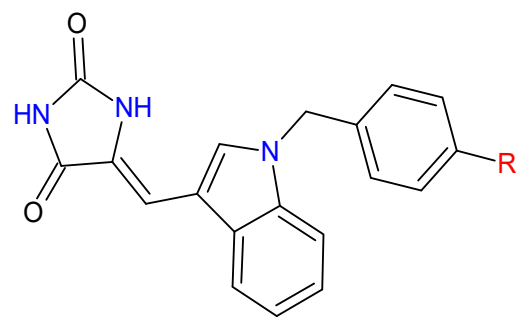

$$
\mathrm{R}=\mathrm{CH},-\mathrm{NO}_{2},-\mathrm{COOCH}_{3}
$$

Fig. 21. Structure of (5Z)-5-[(1-(4-substitutedbenzyl)-1H-indol-3-yl)-methylidene]-imidazolidine-2,4-dione

5-(Aziridin-1-yl)-3-(1H-imidazol-2-yl)-1-methyl-1H-indole-4,7-dione (Fig. 22) has shown good cytotoxicity via forming Hoogsteen-type of hydrogen bonds with DNA and involved DNA cleavage as a result of binding to the major-groove followed by phosphate backbone alkylation. ${ }^{25}$ SpongotineA (Fig. 23) has also shown MRSA PK inhibitory activity. ${ }^{26}$

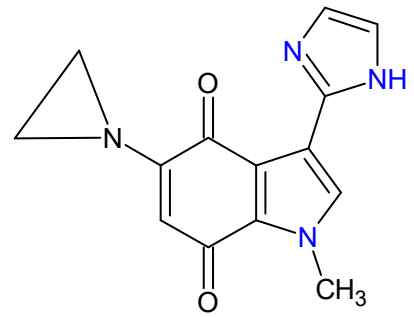

Fig. 22. Structure of5-(Aziridin-1-yl)-3-(1H-imidazol-2-yl)-1-methyl- $1 H$-indole-4,7-dione<smiles>O=C(C1=NC(c2c[nH]c3cc(Br)ccc23)CN1)c1c[nH]c2ccccc12</smiles>

Fig. 23. Structure of Spongotine-A

3-(4,5-Diphenyl-1H-imidazol-2-yl)-1H-indole (Fig. 24) has shown antioxidant activities. ${ }^{27} 3-(1$ (1,2,3,4-Tetrahydronaphthalen-1-yl)-1 $H$-imidazole)-5-(benzyloxy)-1 $H$-pyrrolo[2,3-c]-pyridine (Fig. 25) has reported as an antibiotic and antitumor agent. ${ }^{28}$<smiles>c1ccc(-c2nc(-c3c[nH]c4ccccc34)[nH]c2-c2ccccc2)cc1</smiles>

Fig. 24. Structure of 3-(4,5-Diphenyl-1 $H$-imidazol-2-yl)-1 $H$-indole 


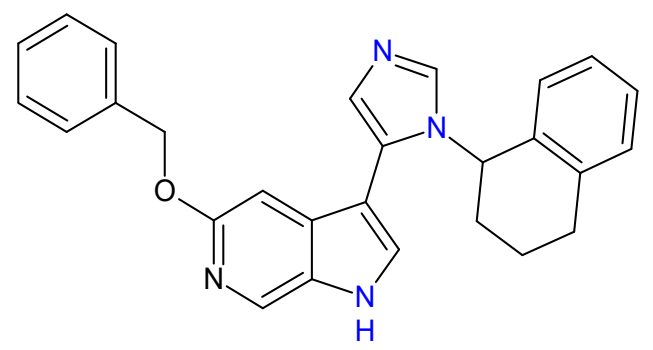

Fig. 25. Structure of 3-(1-(1,2,3,4-Tetrahydronaphthalen-1-yl)-1H-imidazole)-5-(benzyloxy)-1H-pyrrolo[2,3-c]-pyridine

Rajaramana D., Sundararajana G. et al. ${ }^{29}$ described the synthesis of 3-\{1-[2-(3,4dimethoxyphenyl)ethyl]-4,5-diphenyl-1 $H$-imidazol-2-yl $\}-1 H$-indole (Fig. 26) catalysed by $\mathrm{SO}_{4}^{2-} / \mathrm{Y}_{2} \mathrm{O}_{3}$ and reported as antimicrobial agent.<smiles>COc1ccc(CCn2c(-c3c[nH]c4ccccc34)nc(-c3ccccc3)c2-c2ccccc2)cc1OC</smiles>

Fig. 26. Structure of 3-\{1-[2-(3,4-dimethoxyphenyl)ethyl]-4,5-diphenyl- $1 H$-imidazol-2-yl $\}-1 H$-indole

Naureen S., Ijaz F., et al. ${ }^{30}$ synthesized 3-[1-(4-substitutedphenyl)-4,5-diphenyl-1 $H$-imidazol-2yl]-2-(4-substitutedphenyl)-5-substituted- $1 H$-indole derivatives 4 by refluxed of substituted-indole-3carboxaldehyde 1, benzil 2, substituted-aniline $\mathbf{3}$ and ammonium acetate in the presence of acetic acid for 5-6 hours (Scheme 1). These synthesized compounds showed significant biological activities such as 3-[1-(4-methoxyphenyl)-4,5-diphenyl-1H-imidazol-2-yl]-2-(4-methylphenyl)- $1 H$-indole (Fig. 27) and compound 2-(4-bromophenyl)-3-[1-(4-methylphenyl)-4,5-diphenyl-1 $H$-imidazol-2-yl]-1H-indole (Fig. 28) exhibited potent antiurease activity good antioxidant inhibition of $90.3 \pm 0.57 \%$ at $0.5 \mathrm{mM}$ respectively. 3-[1,4,5-Triphenylimidazole-2-yl]-2-phenylindole (Fig. 29) derivatives have been reported as antiurease and antioxidant agent.

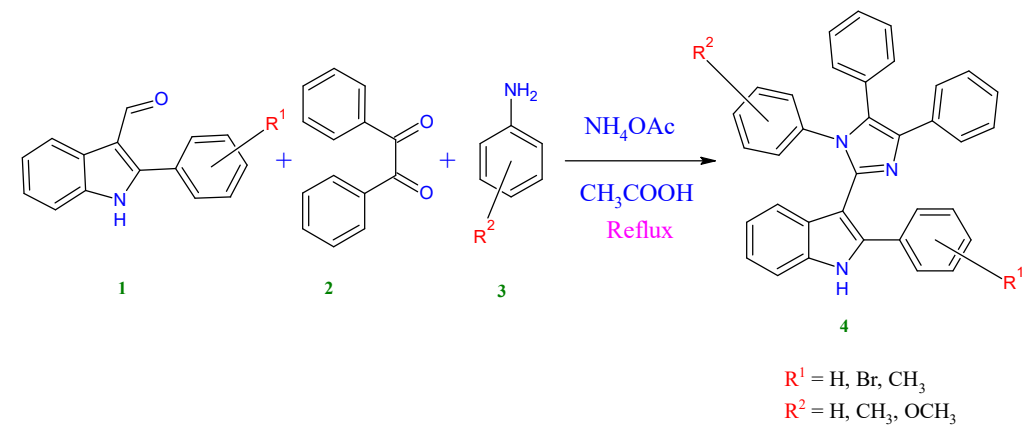

Scheme 1. Synthesis of indolylimidazole derivatives 


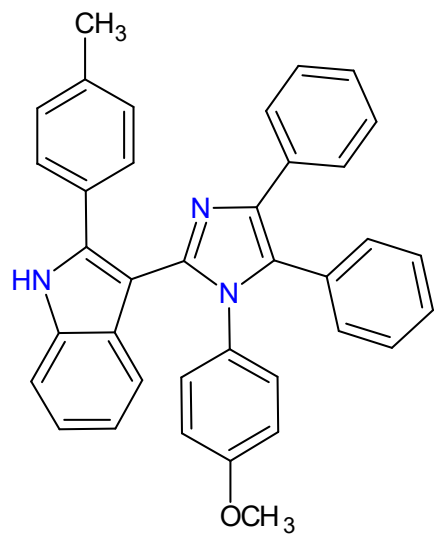

Fig. 27. Structure of 3-[1-(4-methoxyphenyl)-4,5-diphenyl-1H-imidazol-2-yl]-2-(4-methylphenyl)-1 $H$-indole<smiles>Cc1ccc(-n2c(-c3c(-c4ccccc4)[nH]c4ccccc34)nc(-c3ccccc3)c2-c2ccc(Br)cc2)cc1</smiles>

Fig. 28. Structure of 2-(4-bromophenyl)-3-[1-(4-methylphenyl)-4,5-diphenyl- $1 H$-imidazol-2-yl]-1H-indole<smiles>c1ccc(-c2nc(-c3c(-c4ccccc4)[nH]c4ccccc34)n(-c3ccccc3)c2-c2ccccc2)cc1</smiles>

Fig. 29. Structure of 3-[1,4,5-Triphenylimidazole-2-yl]-2-phenylindole

Mahmoodia N. O., Nikokarb I., et al. ${ }^{31}$ synthesized substituted-indolylimidazole derivatives 7 by condensation of mixture of substituted-indole-3-carboxaldehyde 5, benzil, substituted-aniline 6 and ammonium acetate in the presence of $\mathrm{Zn}^{2+} @ \mathrm{KSF}$ at $70^{\circ} \mathrm{C}$ for 40 minute (Scheme 2). These synthesised compounds 3-(1,4,5-triphenyl-1H-imidazol-2-yl)-1H-indole (Fig. 30), 1-Methyl-3-(1-methylphenyl4,5-diphenyl-1 $H$-imidazol-2-yl)-1 $H$-indole (Fig. 31) and 1,4-bis-[3-(1,4,5-triphenyl-1 $H$-imidazol-2yl)-1H-indole]-butane (Fig. 32) showed good antibacterial activities against Micrococcus luteus, Bacillus subtilis and Salmonella enteritis respectively. 


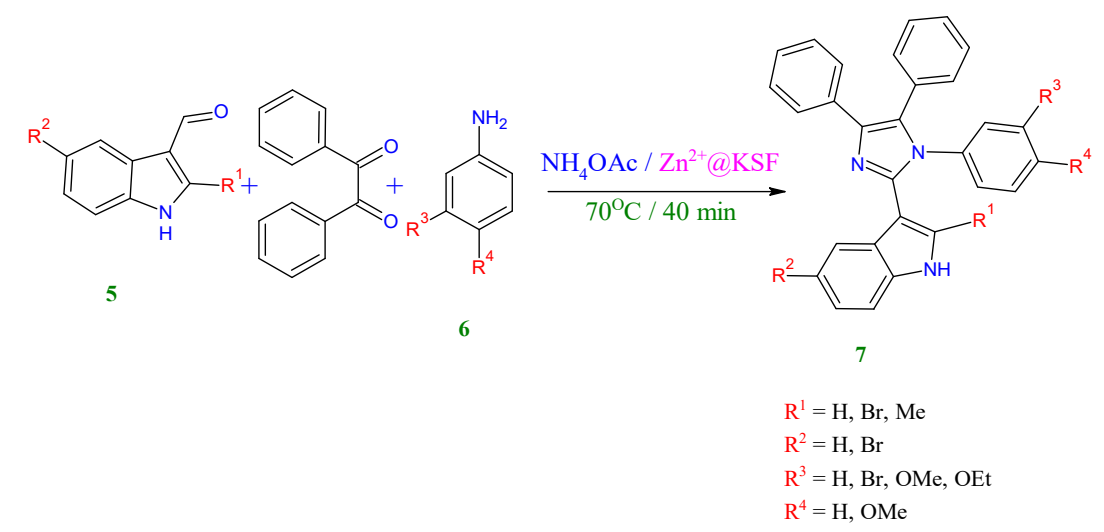

Scheme 2. Synthesis of indolylimidazole derivatives<smiles>c1ccc(-c2nc(-c3c[nH]c4ccccc34)n(-c3ccccc3)c2-c2ccccc2)cc1</smiles>

Fig. 30. Structure of 3-(1,4,5-triphenyl- $1 H$-imidazol-2-yl)-1 $H$-indole<smiles>Cc1ccc(-n2c(-c3c(C)[nH]c4ccccc34)nc(-c3ccccc3)c2-c2ccccc2)cc1</smiles>

Fig. 31. Structure of 1-Methyl-3-(1-methylphenyl-4,5-diphenyl-1 $H$-imidazol-2-yl)-1H-indole<smiles>c1ccc(-c2nc(-c3cn(CCCCn4cc(-c5nc(-c6ccccc6)c(-c6ccccc6)n5-c5ccccc5)c5ccccc54)c4ccccc34)n(-c3ccccc3)c2-c2ccccc2)cc1</smiles>

Fig. 32. Structure of 1,4-bis-[3-(1,4,5-triphenyl-1 $H$-imidazol-2-yl)-1 $H$-indole]-butane 
Nirwan N., Pareek C., et al. ${ }^{32,33}$ synthesized 5-substituted-3-(4,5-diphenyl-1 $H$-imidazol-2-yl)-1Hindole derivatives 9 and 3-(4,5-diphenyl-1-substituted-1 $H$-imidazol-2-yl)-1 $H$-indole derivatives $\mathbf{1 0}$ by the irradiation with microwaves of a mixture of 5-substituted-indole-3-aldehyde $\mathbf{8}$, benzil, substituted-aniline, $\mathrm{NH}_{4} \mathrm{OAc}$, and Amberlyst A-15 at a constant temperature (Scheme 3). These compounds (Fig. 33) showed good antibacterial activities against E. coli and P. aeruginosa. ${ }^{34}$

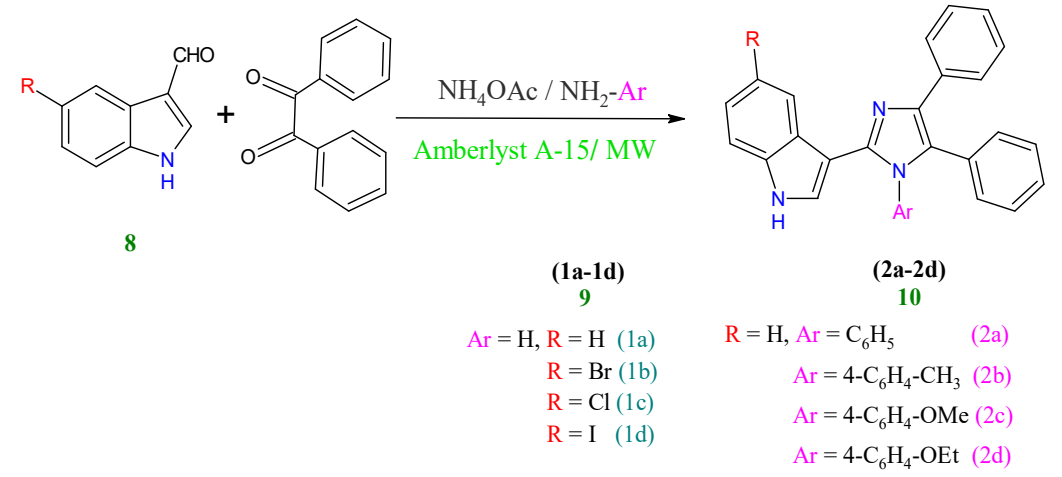

Scheme 3. Synthesis of indolylimidazole derivatives

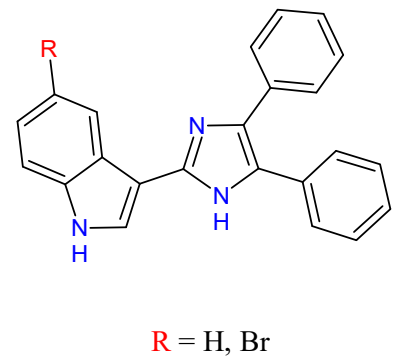

Fig. 33. Structure of indolylimidazole derivatives

Benkli K., Demirayak S. et al. ${ }^{35}$ synthesized 1-substituted-2-(1H-imidazol-1-yl)-3-(4,5-di-[4substituted]phenyl-1 $H$-imidazol-2-yl)-1 $H$-indole derivatives 13 (Fig. 34 to Fig. 39) by refluxed of 2(1H-imidazol-1-yl)-1H-indole-3-carbaldehyde 11, substituted-benzil 12 and ammonium acetate in presence of acetic acid for 2 hours (Scheme 4). Indolylimidazoles 15 such as 1-substituted-2-(1Himidazol-1-yl)-3-(1H-phenantho[5,6- $d]$-imidazol-2-yl)- $1 H$-indole derivatives (Fig. 40) and 1substituted-2-[2-(1H-imidazol-1-yl)-1H-indol-3-yl]-1H-benzimidazole derivatives (Fig. 41) also produced via above described method by using 2-(1H-imidazol-1-yl)- $1 H$-indole-3-carbaldehyde, ammonium acetate and 1,2-diole 14 reactants (Scheme 5). These compounds reported as antifungal and antimicrobial.

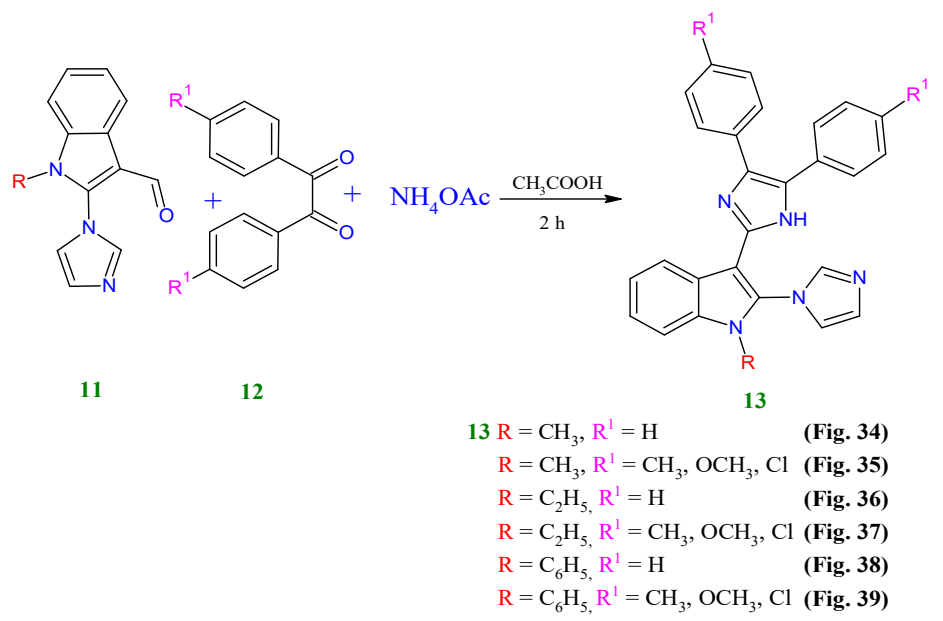

Scheme 4. Synthesis of indolylimidazole derivatives 
<smiles>[R]n1c(-n2ccnc2)c(C=O)c2ccccc21</smiles>

14<smiles>[R]n1c(-n2ccnc2)c(-c2ncc[nH]2)c2ccccc21</smiles>

15

$\begin{aligned} 15 \mathrm{R} & =\mathrm{CH}_{3}, \mathrm{C}_{2} \mathrm{H}_{5}, \mathrm{C}_{6} \mathrm{H}_{5}, \mathrm{CH}(\mathrm{O})=\mathrm{CH}(\mathrm{O})=\text { Phenanthrene-9,10-dione } \\ \mathrm{R} & =\mathrm{CH}_{3}, \mathrm{C}_{2} \mathrm{H}_{5}, \mathrm{C}_{6} \mathrm{H}_{5}, \mathrm{CH}(\mathrm{O})=\mathrm{CH}(\mathrm{O})=\text { Cyclohexa-3,5-diene-1,2-dione }\end{aligned}$

Scheme 5. Synthesis of indolylimidazole derivatives

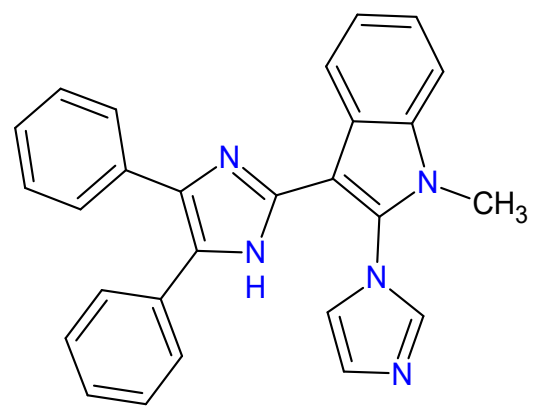

Fig. 34. Structure of 2-(1H-imidazol-1-yl)-1-methyl-3-(4,5- diphenyl-1H-imidazol-2-yl)-1 $H$-indole

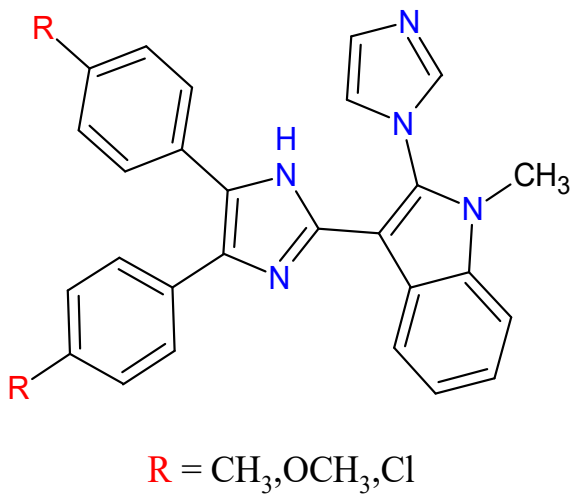

Fig. 35. Structure of 2-(1H-imidazol-1-yl)-1-methyl-3-(4,5-di-[4-substitutedphenyl]-1H-imidazol -2-yl)- $1 H$-indole 


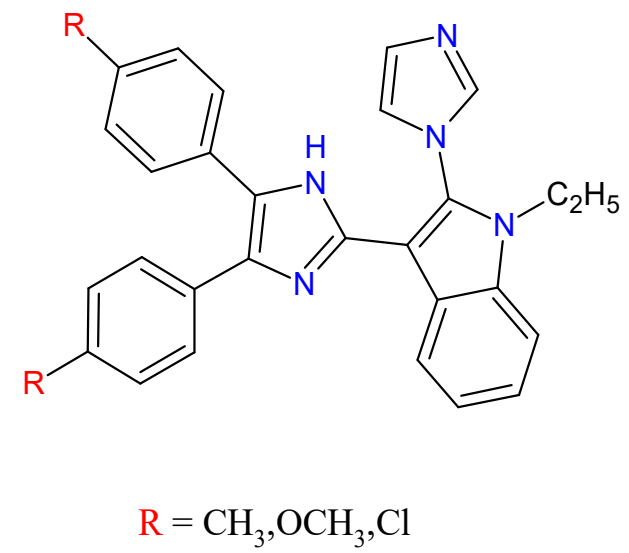

Fig. 37. Structure of 1-Ethyl-2-(1H-imidazol-1-yl)-3-(4,5-di-[4-substitutedphenyl]-1H-imidazol-2-yl)-1 $H$-indole

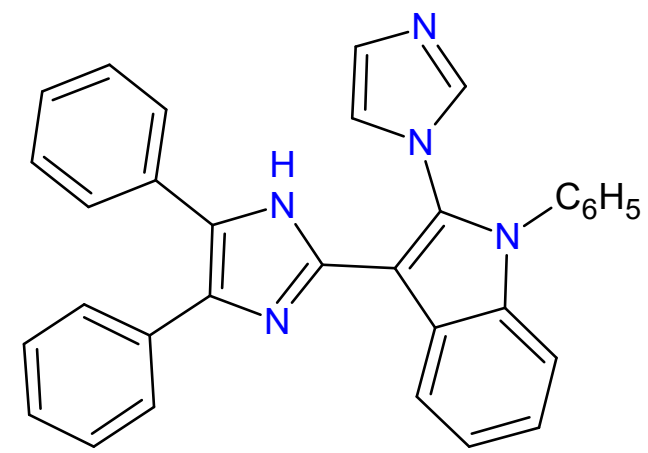

Fig. 38. Structure of 2-(1H-Imidazol-1-yl)-1-phenyl-3-(4,5-diphenyl-1 $H$-imidazol-2-yl)-1 $H$-indole<smiles>[R][R]OCOc1ccc(-c2nc(-c3c(-n4ccnc4)n(CCCCC)c4ccccc34)[nH]c2-c2ccc([R])cc2)cc1</smiles>

Fig. 39. Structure of 2-(1H-Imidazol-1-yl)-1-phenyl-3-(4,5-di-[4-substitutedphenyl]-1H-imidazol-2-yl)- $1 H$-indole 


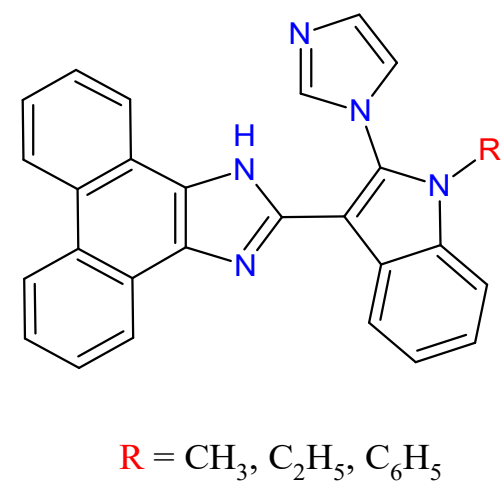

Fig. 40. Structure of 2-(1H-Imidazol-1-yl)-1-substituted-3-(1H-phenantho[5,6- $d]$ imidazol-2-yl)-1 $H$-indole

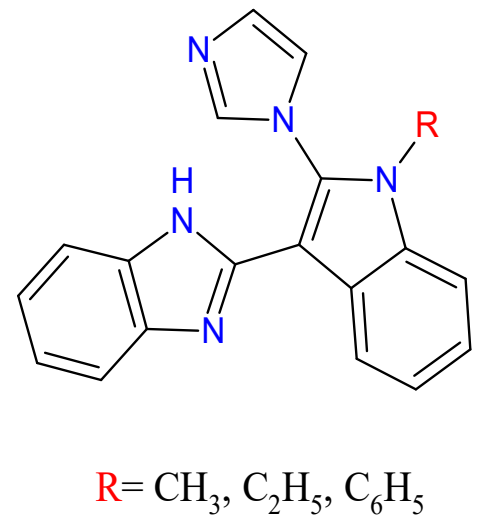

Fig. 41. Structure of 1-Substituted-2-[2-(1H-imidazol-1-yl)-1H-indol-3-yl]-1H-benzimidazole

Biradar J. S., Somappa S. B., et al. ${ }^{36}$ synthesized 2,5-disubstituted-3-(4,5-diphenyl-1H-imidazol2-yl)- $1 H$-indole derivatives 17 by microwave irradiation of the mixture of 2,5-disubstituted-indole-3carboxaldehydes 16, substituted-benzil and ammonium acetate in acetic acid. 2-(2',5'-Disubstituted$1 H$-indol-3-yl)-3,4-dihydroimidazo[4,5-b]indole derivatives 19 were also synthesized by using $1 H$ indole-2,3-dione 18 in same reaction condition (Scheme 6).
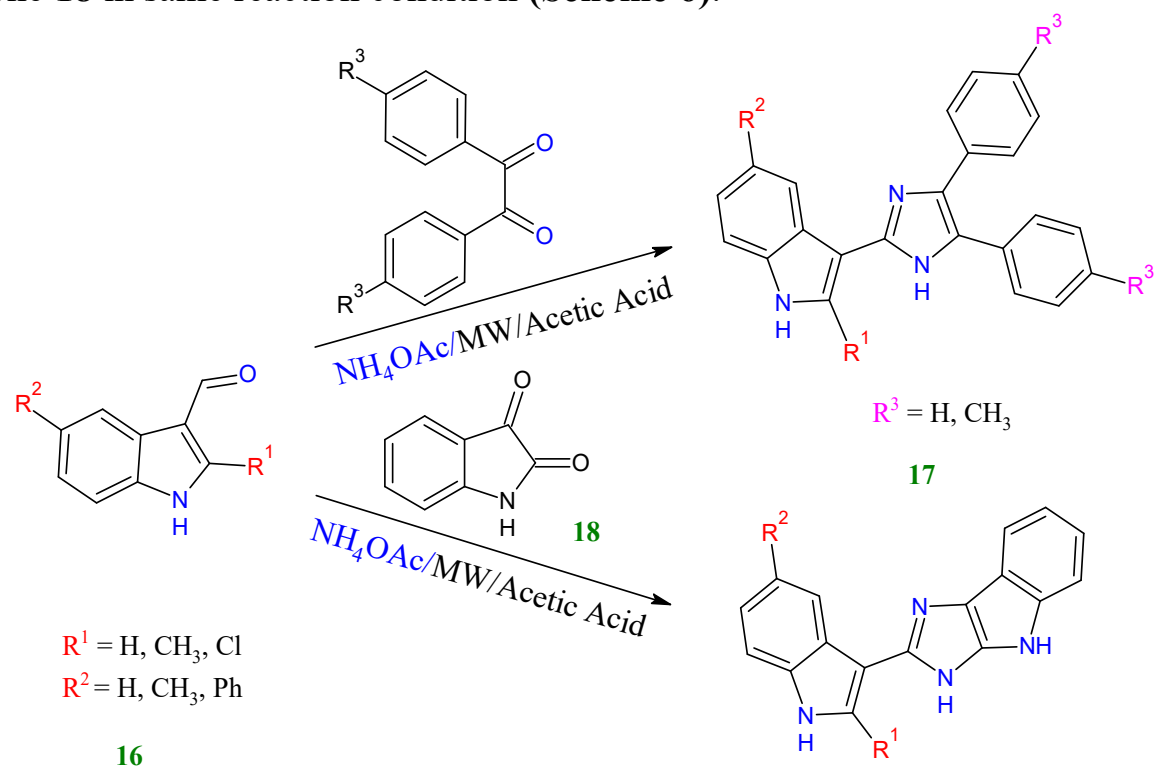

19

Scheme 6. Synthesis of indolylimidazole derivatives 
Nikoofar K, Dizgarani S. M., et al. ${ }^{37}$ described the synthesis of 3-(4,5-diphenyl-1H-imidazol-2-yl)$1 H$-indole 20 and 3-(1,4,5-triphenyl-1 $H$-imidazol-2-yl)- $1 H$-indole 21 by condensation of benzil, indole-3-carbaldehyde, amine and ammonium acetate in the presence of $\mathrm{HNO}_{3} @$ nano $\mathrm{SiO}_{2}$ at $100^{\circ} \mathrm{C}$ for 6.30 hours and 5.10 hours in 74\% and 76\% yields respectively (Scheme 7).

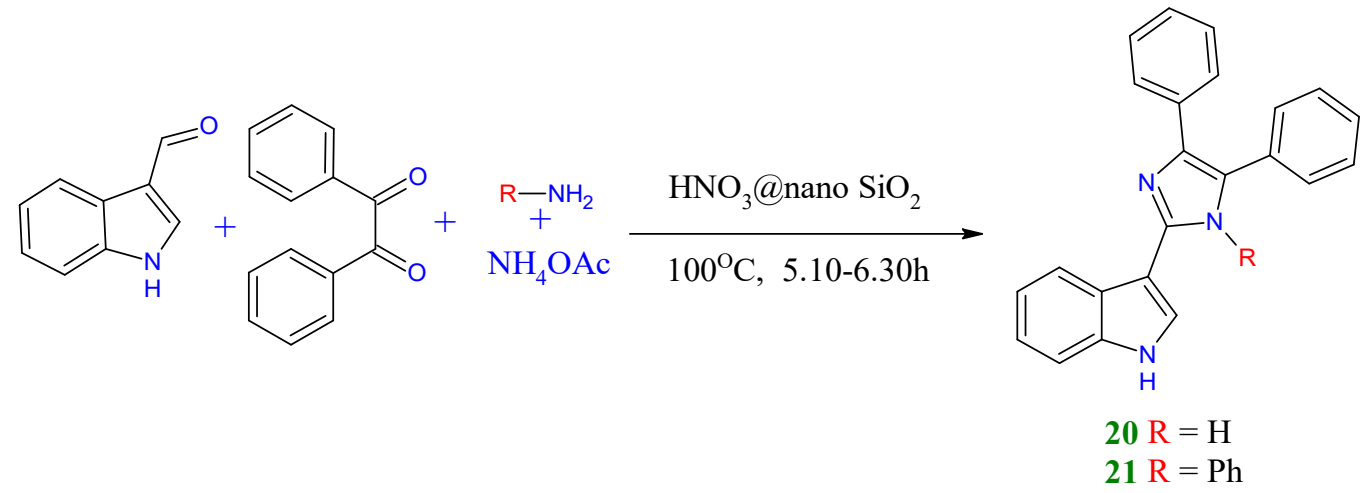

Scheme 7. Synthesis of indolylimidazole derivatives

Kelarev V. I., Remezov A. S., et al. ${ }^{38}$ synthesized 5-(substituted-methylidene)-2-phenyl-3-(2phenyl-1 $H$-indol-3-yl)-3,5-dihydro- $4 H$-imidazol-4-one derivatives 24 by the reaction of 2-phenyl-1Hindol-3-amine 22 and 4-(substituted-methylidene-2-phenyl-1,3-oxazol-5(4H)-one 23 (Scheme 8).

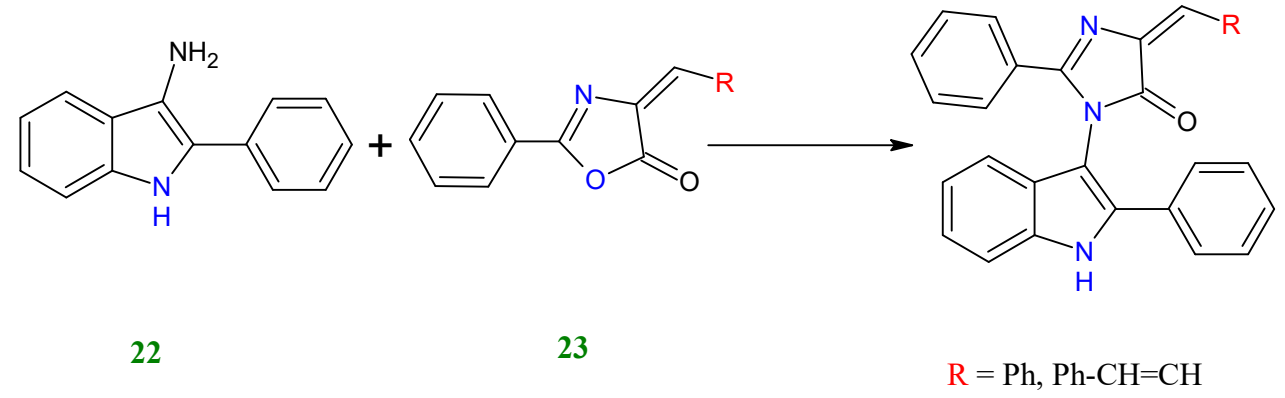

Scheme 8. Synthesis of indolylimidazole derivatives

Molina P., Fresneda P. M., et al. ${ }^{39}$ produced 3-(1H-imidazol-2-yl)-1H-indole 27 by two steps region-selective method by reaction of 2-azido-1-(1H-indol-3-yl)-ethan-1-one 25 and substitutedcarboxylic acid $\mathbf{2 6}$ in the presence of tri-methyl phosphine followed by cyclization using ammonium acetate under microwave irradiation and obtained 35-53\% yield (Scheme 9).

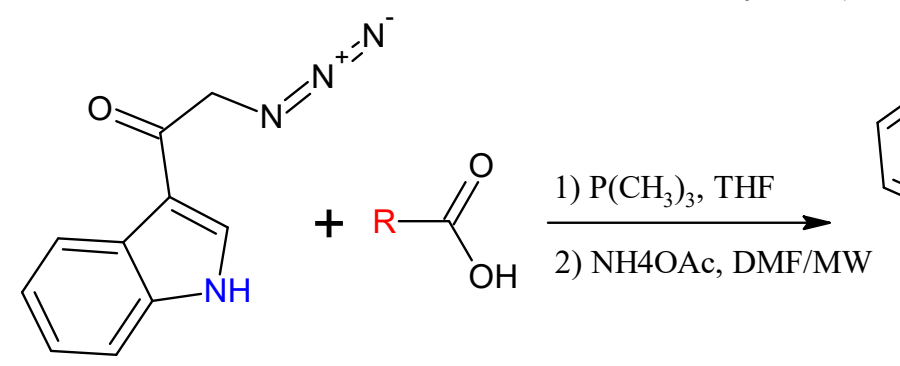

25<smiles>[R]c1c[nH]c(-c2c[nH]c3ccccc23)n1</smiles>

27

Scheme 9. Synthesis of indolylimidazole derivatives

Kobori T., Hatanaka Y., et al. ${ }^{40}$ prepared 2-(1H-indol-3-yl)-1H-imidazole-1,3(2H)-substituteddicarbaldehyde derivatives 31 by heating imidazole 28 and acyl chloride 29 mixture followed by reaction of obtained diacetyl imidazolium salts $\mathbf{3 0}$ with 1,2-disubstituted-indole in the presence of acyl chloride for 2 hours (Scheme 10). 


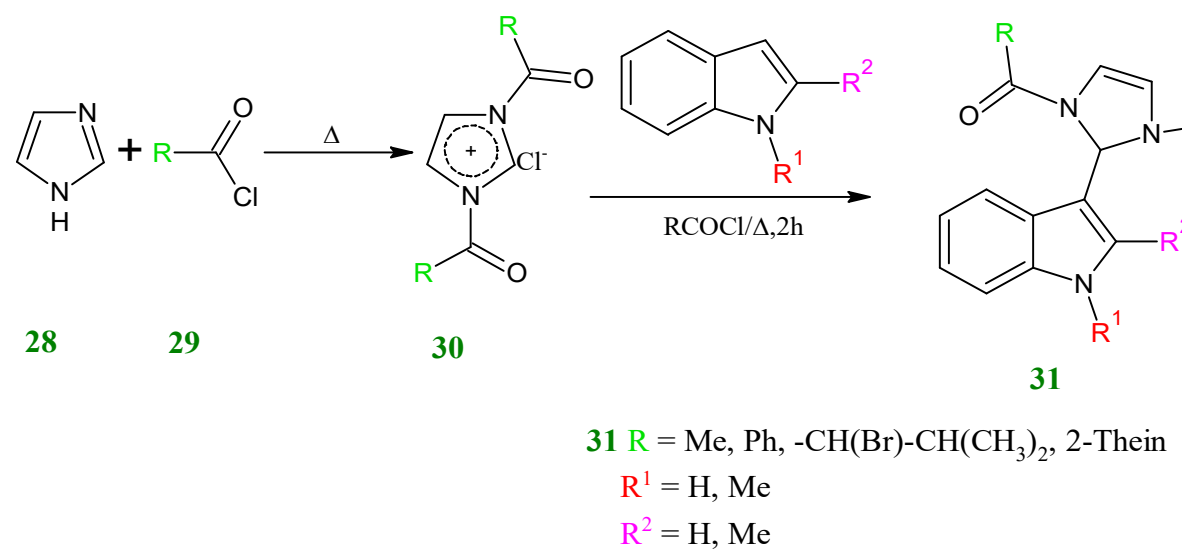

Scheme 10. Synthesis of indolylimidazole derivatives

Kobori T., Hatanaka Y., et al. ${ }^{41}$ synthesized 3-\{5-[4-(benzyloxy)-phenyl]-2-phenyl-1 $H$-imidazol4-yl $\}-1 H$-indole 36 by reaction of indolylmagnesium bromide 32 with [4-(benzyloxy)-phenyl]-acetic acid 33 followed by oxidation of obtained 2-[4-(benzyloxy)phenyl]-1-(1H-indol-3-yl)ethan-1-one 34 with selenium dioxide. Then reaction of 1-[4-(benzyloxy)-phenyl]-2-(1H-indol-3-yl)-ethane-1,2-dione 35 with benzaldehyde and ammonium acetate (Scheme 11). This Compound 36 reported as phosphodiesterase inhibitors.

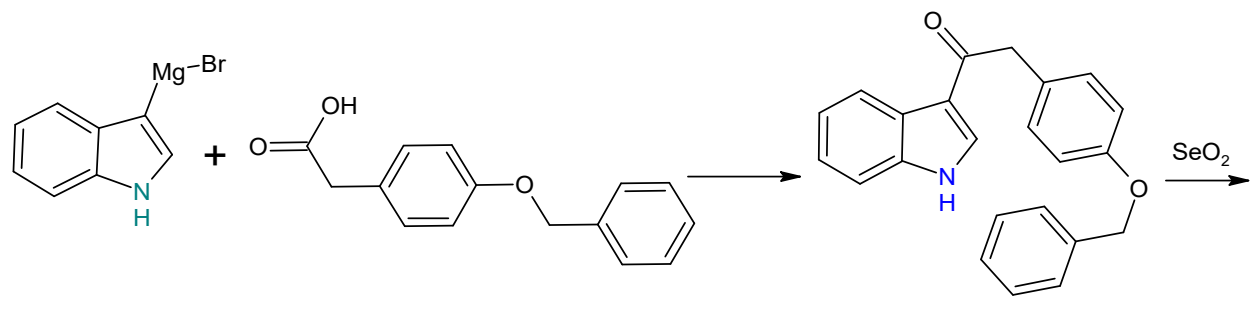

32

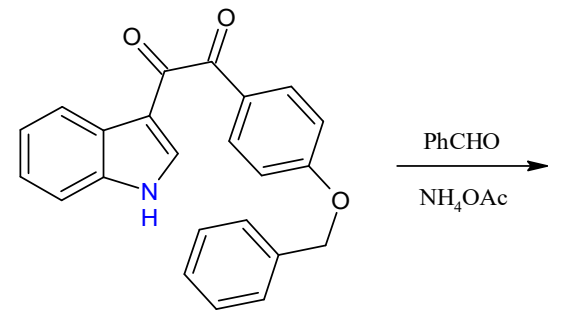

35

33

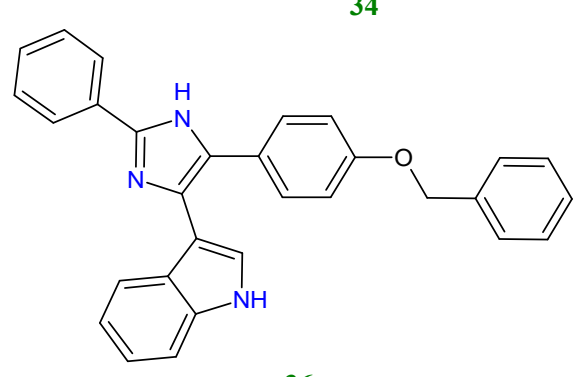

36

Scheme 11. Synthesis of indolylimidazole derivatives

Ota T., Nakanishi M., et al. ${ }^{42,43}$ synthesized 3-[2-substituted-5-(4-methoxyphenyl)-1 $H$-imidazol-4yl]-1H-indole 41 by reaction of indole 37 with ethanedioyl dichloride $\mathbf{3 8}$ followed by reaction of obtained (1H-indol-3-yl)(oxo)acetyl chloride 39 and anisole in the presence of aluminium chloride to form 1-(1H-indol-3-yl)-2-(4-methoxyphenyl)ethane-1,2-dione 40. Then the refluxed of product 40, aldehyde, ammonium acetate in the presence of acetic acid (Scheme 12). The compounds 41 reported as anti-inflammatory, analgesic, and antipyretic agents. 
<smiles>COc1ccccc1CC(=O)C(=O)C(=O)c1c[nH]c2ccccc12</smiles>

37

38

39<smiles>COc1ccc(C(=O)C(=O)c2c[nH]c3ccccc23)cc1</smiles>

40<smiles>[R]c1nc(-c2c[nH]c3ccccc23)c(-c2ccc(OC)cc2)[nH]1</smiles>

41

$$
41 \mathrm{R}=4-\mathrm{C}_{6} \mathrm{H}_{4} \mathrm{Me}, 4-\mathrm{C}_{6} \mathrm{H}_{4} \mathrm{~F}, 2 \text {-Benzofuranyl }
$$

Scheme 12. Synthesis of indolylimidazole derivatives

1,5-disubstitutes-3-[5-(4-methoxyphenyl)-2-substitutes- $H$-imidazol-4-yl]-1 $H$-indole derivatives 44 synthesized by reflux of 1-(1,5-disubstituted-1H-indol-3-yl)-2-(4-methoxyphenyl)ethane-1,2-dione 42, substituted-aldehyde 43 and ammonium acetate in the presence of acetic acid ${ }^{44-46}$ (Scheme 13). These compounds $\mathbf{4 4}$ reported as phosphodiesterase inhibitors.

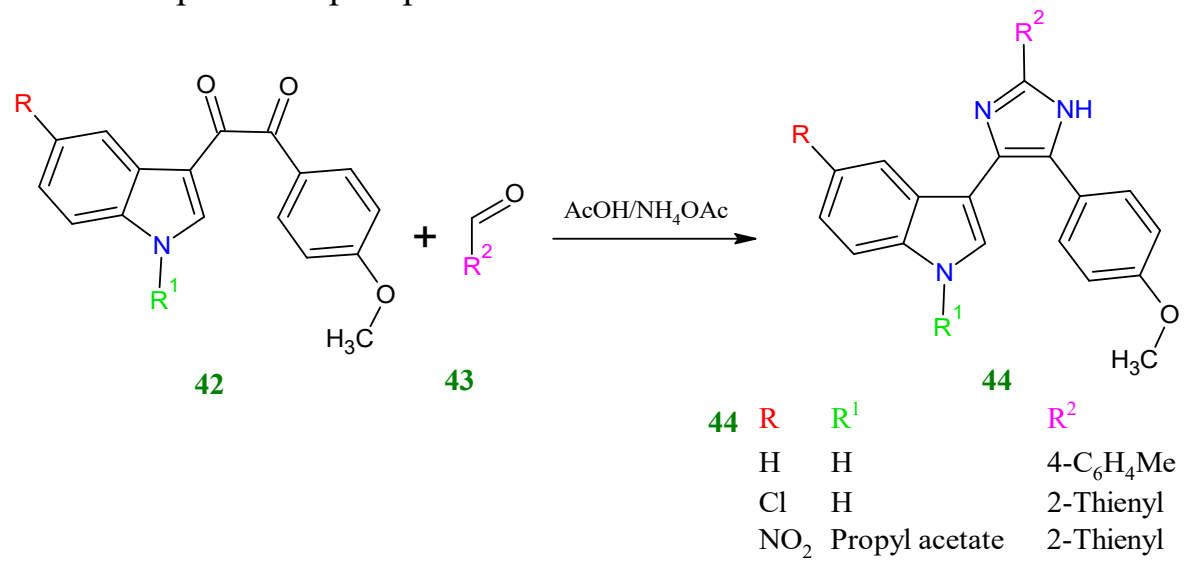

Scheme 13. Synthesis of indolylimidazole derivatives

3-(4,5-diphenyl-1 $H$-imidazol-2-yl)-2-methyl-1 $H$-indole 46 synthesized by reflux of 2-methyl-1 $H$ indole-3-carbaldehyde 45, benzil and ammonium acetate in the presence of acetic acid ${ }^{47}$ (Scheme 14).<smiles>Cc1[nH]c2ccccc2c1C=O</smiles>

Scheme 14. Synthesis of indolylimidazole derivatives 
1-[2-Azido-1-(methoxymethyl)-1H-indol-3-yl]-2,2-dihydroxyethan-1-one 49 prepared by oxidation of 1-[2-chloro-1-(methoxymethyl)-1H-indol-3-yl]ethan-1-one $\mathbf{4 7}$ by the selenium dioxide followed by reaction of obtained $96 \%$ yield of 1-[2-chloro-1-(methoxymethyl)- $1 H$-indol-3-yl]-2,2dihydroxyethan-1-one $\mathbf{4 8}$ with polymeric quaternary ammonium azide (QN3) in 80\% yield. 5-[2chloro-1-(methoxymethyl)-1 $H$-indol-3-yl]-2-(dimethylamino)-1,5-dihydro-4 $H$-imidazol-4-one 50 and 5-[2-amino-1-(methoxymethyl)-1 $H$-indol-3-yl]-2-(dimethylamino)-1,5-dihydro-4H-imidazol-4-one 51 synthesized by reaction of compounds $\mathbf{4 8}$ and 49 with $N, N$-dimethylguanidine in $91 \%$ and $95 \%$ yields respectively ${ }^{48}$ (Scheme 15).

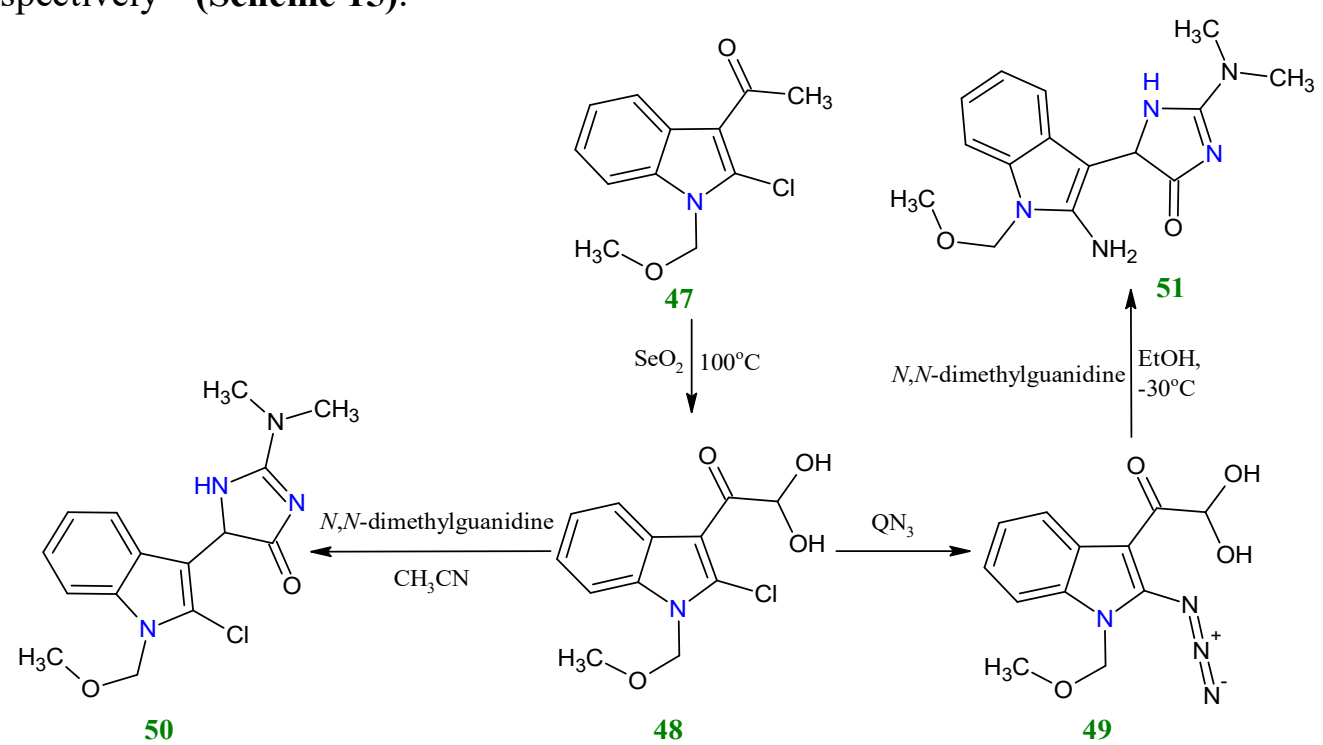

Scheme 15. Synthesis of indolylimidazole derivatives

Shaterian H.R., Ranjbar M., et al ${ }^{49}$. described the synthesis of 3-[1-(4-methylphenyl)-4,5-diphenyl$1 H$-imidazol-2-yl]-1H-indole 52 by condensation reaction of benzil with indole-3-carbaldehyde, 4methylaniline, ammonium acetate in the presence of triphenyl(propyl-3-sulphonyl)phosphonium toluenesulfonate at $100^{\circ} \mathrm{C}$ for 35 minute in $82 \%$ yields. Benzoin was used for same reaction for 40 minute, $89 \%$ yields was obtained (Scheme 16).

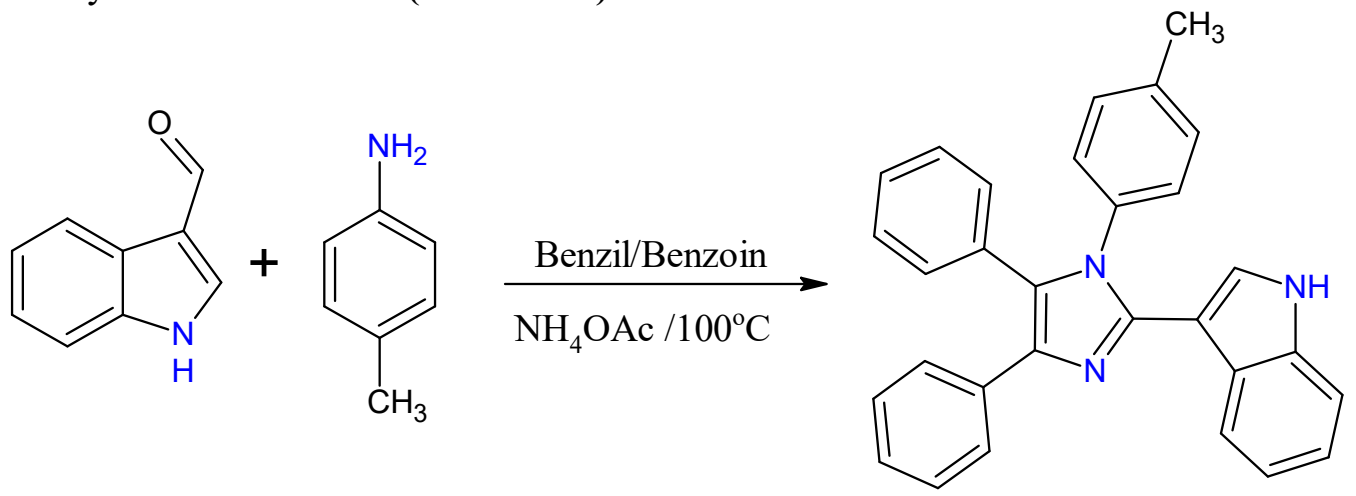

52

\section{Conclusion}

Scheme 16. Synthesis of indolylimidazole derivatives

Indolylimidazole compounds play an important role in the field of medicinal science because of their wide spectrum of pharmacological activities as reported in the reviewed article. Many bioactive natural and synthesized compounds have been reported which contain the important structural moiety of indolylimidazole. These kinds of compounds synthesized by using different types of catalyst, such as strong protic acid $\mathrm{HNO}_{3} @$ nano $\mathrm{SiO}_{2}, \mathrm{Zn}^{2+} @ \mathrm{KSF}$, acetic acid, QN3, Amberlyst A-15 and 
microwave irradiation. The compounds that comprise the core of indolylimidazole skeleton have shown various bioactivities such as inhibitor against protein kinase $\mathrm{C}$, interleukin-6 production, topoisomerase, phosphodiesterase and cyclin-dependent kinase-4 and cerb $\beta$-2 kinase. These compounds also exhibit cytotoxicity against a panel of human cancer cell lines, good cytotoxicity by forming Hoogsteen-type hydrogen bonds with DNA and good antibacterial activities against $E$. coli and $P$. aeruginosa, M. luteus, B. subtilis, S. enteritis, Sarcinalutea, and C. xerosis. These compounds also show anti-plasmodial, antidepressants, antimicrobial, antiurease, radio sensitizing, antifungal, antioxidants, anti-inflammatory, analgesic, antipyretic, phosphodiesterase and anticancer activities. Thus, this review paper reports about different kinds of synthetic methods and valuable bioactivities of indolylimidazole derivatives.

\section{Acknowledgments}

The authors would like to express their sincere thanks to Dr. K.K. Verma, Assistant Professor, SNKP Govt. College, Neem Ka Thana, Dr. Rohitash Sharma, Assistant Professor, Department of Microbiology, JLN Medical College, Ajmer and Mr. Hemant Kumar for their valuable criticism and helpful discussions. One of the authors Narendra Nirwan is thankful to Dr. G.S. Chauhan, Deputy Secretary, UGC, Bhopal for his help and motivation and to UGC-CSIR for granting TRF to him.

\section{References}

1 Kawasaki I., Katsuma H., Nakayama Y., Yamashita M. Y., \& Ohta S. (1998) Total Synthesis of Topsentin, Antiviral and Antitumor Bis(indolyl)imidazole. Heterocycles, 48 (9) 1887-1901.

2 Burres N. S., Barber D. A., Gunasekera S. P., Shen L.L., \& Clement J. J. (1991) Antitumor activity and biochemical effects of Topsentin. Bio. Pharm., 42(4) 745-751.

3 Bartik K., Braekman J. C., Daloze D., Stoller C., Huysecom J., Vandevyver G., et al. (1987) Topsentins, new toxic bis-indole alkaloids from the marine sponge Tepsentiagenitrix. Canadian J. of Chem., 65(9) 2118-2121.

4 Morris S. A., \& Andersen R. J. (1990) Brominated bis(indole) alkaloids from the marine sponge hexadella sp. Tetrahedron, 46(3) 715-720.

5 Sakemi S., \& Sun H. H. (1991) Nortopsentins A, B, and C., Cytotoxic and antifungal imidazolediylbis[indoles] from the sponge Spongosoritesruetzleri. J. of Org. Chem., 56(13) 4304-4307.

6 Bao B., Sun Q., Xinsheng Y., Hong J., Lee C. O., Sim C. et al. (2005) Cytotoxic bisindole alkaloids from a marine sponge Spongosorites sp. J. of Nat. Prod., 68(5) 711-715.

7 Tsujii S., Rinehart K. L., Gunasekera S. P., Kashman Y., Cross S. S., Lui M. S., et al. ( 1988) Topsentin, bromotopsentin, and dihydrodeoxybromotopsentin: antiviral and antitumorbis(indolyl) imidazoles from Caribbean deep-sea sponges of the family Halichondriidae, Structural and synthetic studies. J. of Org. Chem., 53(23) 5446-5453.

8 Shin J., Seo Y., Cho K. W., Rho J. R., \& Sim C. J. (1999) New bis(indole) alkaloids of the topsentin class from the sponge Spongosoritesgenitrix. J. of Nat. Prod., 62(4) 647-649.

9 Casapullo A., Bifulco G., Bruno I. and Riccio R. (2000) New Bisindole Alkaloids of the Topsentin and Hamacanthin Classes from the Mediterranean Marine Sponge Rhaphisialacazei. J. of Nat. Prod., 63(4) 447-451.

10 McConnell O. J., Saucy. G., \& Jacobs R. (1994). US Patent 5,290,777.

11 Wright A. E., Pomponi S. A., \& Roberts J. A. (1999). Patent WO 9,942,092.

12 Sakemi, S., \& Sun, H. H. (1991). Nortopsentins A, B, and C. Cytotoxic and antifungal imidazolediylbis [indoles] from the sponge Spongosorites ruetzleri. J. of Org. Chem., 56(13), 4304-4307.

13 Alvarado S., Roderts B. F., Wright A. E., \& Chakrabarti D. (2013) The Bis(Indolyl)Imidazole Alkaloid Nortopsentin-A Exhibits Antiplasmodial Activity. Antimicrobial Ag. and Chemo., 57(5) 2362-2364. 
14 Bewely C. A., \& Faulkner D. J. (1998) Lithistid sponges: Star performers or hosts to the stars. Angewandte Chem. International Ed. in Eng., 37(16) 2162-2178.

15 Hogan I. T., \& Sainsbury M. (1984) The synthesis of dendrodoine, 5-[3-(N,N-dimethylamino1,2,4-thiadiazolyl]-3-indolylmethanone, a metabolite of the marine tunicate dendroda grossular. Tetrahedron, 40(4) 681-682.

16 Capon R. J., Peng C., \& Dooms C. (2008) Trachycladindoles A-G: Cytotoxic heterocycles from an Australian marine sponge, Trachycladuslaevispirulifer. Org. \& Biomo. Chem., 6(15) 27652771.

17 Hlasta D. J. (1991). US patent 5,017,584. Chem. Abstr., 115, 232,249.

18 Karabelas K., Lepisto M., \& Sjo P. (2000). Word patent WO 2,000,078,750. Chem. Abstr., $13,471,594$.

19 Karabelas K., Lepisto M., \& Sjo, P. (1999). Word patent WO 9,932,483. Chem. Abstr., 13, 158,823 .

20 Levy, L. (1977) Proceedings, Soc. Exp. Biol. Med., 153 34-36. Chem. Abstr., 8,625,978.

21 Hoff, D. R. (1970). DE. 1,962,822. Chem. Abstr., 7,387,931.

22 Sato, H., Tsuda, M., Watanabe, K., \& Kobayashi, J. (1998) Rhopaladins A-D, new indole alkaloids from marine tunicate Rhopalaea sp. Tetrahedron, 54(30) 8687-8690.

23 Doemling A., \& Beck B. (2001). Word patent WO 2001,025,213. Chem. Abstr., 134,295,819.

24 Reddy Y. T., Konjeti R. S., Nidhish S., Reddy P. N., Freeman M. L., \& Peter A. C. (2010) Novel substituted (Z)-5-((N-Benzyl-1H-indol-3-yl)methylene)imidazolidine-2,4-diones and 5((N-Benzyl-1H-indol-3-yl)methylene)pyrimidine-2,4,6(1H,3H,5H)-triones as Potent Radiosensitizing Agents. Bioorg. and Medi. Chem. Lett., 20(2) 600-602.

25 Roffey J. R. A. (1996) The Synthesis of Indole Containing Anticancer Compounds, $\mathrm{PhD}$ thesis, Loughborough University, UK.

26 Zoraghi R., Worrall L., See R. H., Strangman W., Popplewe W. L., Gong H., et al. (2011) MRSA Pyruvate Kinase as a Target for Bis-indole Alkaloids with Antibacterial Activities. $J$. of Bio. Chem., 286(52) 44716-44725.

27 Singh P., Kumar R., Tiwari S., Khanna R. S., Tewari A. K., Khanna H. D., et al. (2015) Docking, Synthesis and Evaluation of Antioxidant Activity of 2,4,5-Triaryl Imidazole. Clini. \& Medi. Biochem., 1(1) 1-4.

28 Hilya V. P., Grishko L. G., Golubushina G. M., Arkhipova N. N. and Turov A. V. (1994) Khim. Geterotsikl. Soedin., 1063-1070. Chem., Abstr. 122,314,495.

29 Rajaramana D., Sundararajana G., Loganathb N. K., \& Krishnasamya K. (2017) Synthesis, molecular structure, DFT studies and antimicrobial activities of some novel 3-(1-(3,4dimethoxyphenethyl)-4,5-diphenyl-1H-imidazol-2-yl)-1H-indole derivatives and its molecular docking studies. J. of Molec. Stru., 1127 597-610.

30 Naureen S., Ijaz F., Munawar M. A., Asif N., Chaudhary F., Ashraf M, et al. (2017) Synthesis of tetrasubstituted imidazoles containing indole and their antiurease and antioxidant activities. J. of the Chil. Chem. Soci., 62(3) 3583-3587.

31 Mahmoodia, N. O., Nikokarb, I., Farhadia, M., \& Ghavidasta, A. (2014) One-pot Multicomponent Synthesis of Mono- and Bis-indolylimidazole Derivatives Using Zn2+@KSF and Their Antibacterial Activity. Zeitschrift für Naturforschung B, 69B(6) 715-720.

32 Nirwan, N., Pareek, C., \& Swami, V. K. (2018) An Efficient Green Synthesis of Substituted Indolylimidazole Derivatives by Employing Reusable Catalyst under Microwave Irradiation. Indian J. of Hetero. Chem., 28(02) 249-54.

33 Nirwan, N., \& Pareek, C. (2017) Synthesis of 2,4,5-trisubstituted imidazole and 4,5disubstituted indolylimidazole derivatives by using Amberlyst A-15 as green, recyclable catalyst. Int. J. Sci. Res. Sci. and Tech., 8(3) 76-82.

34 Pareek, C., Pareek, D., Nirwan, N., \& Jain, A. (2018) An Efficient Combinatorial Approach for Beta-Lactam Antibiotics with Novel Adjuvants against Gram-Negative Organisms to Combat Multi-Drug Resistance. Int. Acade. Con. Appl. Res. Eng. Sci. Tech., Brussels, Belgium. Diamond Scientific Publication: Lithuania, 134-43. 
35 Benkli, K., Demirayak, S., Karaburun, N. G., Nuri, K., Iscan, G., \& Ucucu, U. (2004) Synthesis and antimicrobial activities of some imidazole substituted indoles. Indian J. of Chem., 43B(1) 174-179.

36 Biradar, J. S., Sasidhar, B., Somappa, S. B., \& Mugali, P. S. (2012) One-pot, solvent-free synthesis of 2,5-disubstituted indolylimidazoles by microwave irradiation. Der Pharm. Chem., 4(1) 437-41.

37 Nikoofar, K., \& Dizgarani S. M. (2017) $\mathrm{HNO}_{3} @$ nano $\mathrm{SiO}_{2}$ : An efficient catalytic system for the synthesis of multi-substituted imidazoles under solvent-free conditions. J. of Saudi Chem. Soci., 21(7) 787-94.

38 Kelarev, V. I., Remezov, A. S., Karakhanov, R. A., Polivin, Y. N., et al. (1993) Vysshikh Uchebnykh Zavedenii. Kh. Khim. Tekhn. 35, 84-88. Chem Abstr., 1,186,915.

39 Molina, P., Fresneda, P. M., \& Sanz M. A. (1998). Tetrahedron, 54, 9623-38.

40 Kobori, T., Hatanaka, Y., Ota, T., Nakanishi, M., et al. (1999). JP patent 11,199,582. Chem Abstr., 13,197,622.

41 Kobori T., Hatanaka Y., Ohjta T., Nakanishi M., et al. (1999). JP patent 11,199,583. Chem Abstr., 13,197,623.

42 Ota T., Nakanishi M., Tomisawa K., Kobori T., et al. (1999). Word patent WO 9,935,142. Chem Abstr., 13,173,652.

43 Ohta T., Nakanishi M., Tomizawa K., Kobori T., et al. (1999). JP patent 11,228,570. Chem Abstr., 131,170,350.

44 Ota T., Nakanishi M., Tomisawa K., Kobori T., et al. (1999). JP patent 11,228,572. Chem Abstr., 131,170,351.

45 Biradar J. S., Mugali P. S., Somappa S. B. and Rajesab P. (2008). Org. Chem. Indian J. 4, 40811. Chem Abstr., 15,237,464.

46 Fresneda, P. M., Molina, P., \& Sanz, M. A. (2001). Synlett, 218-21. Chem Abstr., 134,281,011.

47 Velsicol Chemical Corp. (1975). USA NL patent 7317578. Chem Abstr., 84,164,785.

48 Papaioannou C. G. (1972). US patent 3673208. Chem Abstr., 7,788,507.

49 Shaterian H. R., Ranjbar M., \& Azizi K. (2011) Synthesis of highly substituted imidazoles using Bronsted acidic ionic liquid, Triphenyl(propyl-3-sulphonyl)phosphonium toluenesulfonate, as reusable catalyst. J. of the Iranian Chem. Soci., 8(4) 1120-1134.

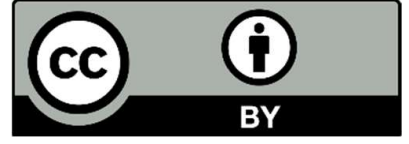

(C) 2020 by the authors; licensee Growing Science, Canada. This is an open access article distributed under the terms and conditions of the Creative Commons Attribution (CC-BY) license (http://creativecommons.org/licenses/by/4.0/). 